Zeszyty Naukowe Szkoły Głównej Gospodarstwa Wiejskiego

Ekonomika i Organizacja Gospodarki Żywnościowej nr 108, 2014: 5-16

Jadwiga Zaród

Wydział Ekonomiczny

Zachodniopomorski Uniwersytet Technologiczny w Szczecinie

\title{
The risks associated with agricultural production in the average farm in Poland
}

\section{Introduction}

Risk can be described as an uncertain phenomenon, the occurrence of which will negatively affect for the business activity. According to Miller et al. [2004], agriculture includes the following risk categories: production risk (caused by weather fluctuations, pests, crop and livestock diseases), price risk (caused by price fluctuations), calamity risk (resulting from force majeure events such as fires, floods, hurricanes etc.) and technological risk (resulting from continued progress, new technology and production method adaptation). The most common risk associated with Polish agriculture is the production and price risk, as altering crops and unstable prices cause fluctuations of acquired agricultural income. Linear-dynamic models with random goal function parameters allow for estimation of risk, related to unfavorable natural and economic conditions. The risk is measured by standard deviation [Jajuga 2007, Kuziak 2011] determined in this work on the basis of variance and covariance matrix of agricultural income acquired in several consecutive years. The production plans acquired from optimal solutions will allow for making the most favorable decision, in given conditions, on the production structure, its profitable trends, amount of agricultural income and the risk related to its realization. The goal of this article is to indicate risk related to the acquisition of agricultural income in an average Polish farm, determined with stochastic programming methods.

\section{Research method}

The main research method of the work is dynamic stochastic programming, where randomness is related to goal function parameters. It allows for inclusion of phenomena altering in time (crops, agricultural products and production 
materials' prices and services). Mathematical formulation of the linear-dynamic optimization model, adapted to the needs of agriculture, takes the form of [Krawiec 1991]:

$$
\begin{aligned}
& \begin{array}{l}
a x(t) \leq b(t) \quad \text { limiting conditions } \\
x(t+1) \leq x(t)+f_{t}[x(t), u(t)] \quad \text { dynamics equations }
\end{array} \\
& \begin{array}{r}
{\left[g(t+1)^{T} u(t) \geq[h(t+1)]^{T} x_{Z}(t+1)\right]} \\
\quad \text { eed balances (from livestock production model) }
\end{array} \\
& \begin{array}{c}
Z=\sum t\left[m(t)^{T} u(t)+w(t+1)^{T} x(t+1)\right] \quad \text { control criterion } \\
x(t) \geq 0, \quad u(t) \geq 0 \quad \text { boundary conditions }
\end{array}
\end{aligned}
$$

where:

$t$ - states (consecutive years of farm management), $t=0,1,2, \ldots, k$,

$a-$ technical and economic parameters' vector,

$b(t)$ - subsequent states' limits vector,

$x(t)$ - state vector,

$u(t)$ - control vector,

$g(t+1)$ - fodder crop unit efficiency (yield) vector,

$h(t+1)$ - annual individual demand for feed and crop materials' vector,

$x_{z}(t+1)$ - livestock state in the year $t+1$ vector,

$m(t)$ - goal function coefficients to state $t$ vector,

$w(t+1)$ - goal function coefficients in the year $t+1$ vector.

It should be assumed that the initial system state in the $t=0$ moment is known and describes the crop acreage and livestock state in the moment preceding the first year of research.

Vector of the $x(t)$ state takes the form:

$$
x(t)=\left[x_{t}(t), x_{p}(t), x_{r}(t)\right]=\left[x_{l}(t), \ldots, x_{n}(t)\right]
$$

where:

$x_{t}(t)$ - commodity operations' state vector (it describes the acreage of forage crops grown in the year $t$ and animal classes and species that yield commodity production in the year $t$, like milk, meat),

$x_{p}(t)$ - subsistence operations' state vector (it describes the acreage of forage crops grown in the year $t$ and animal classes and species that do not yield commodity production),

$x_{r}(t)$ - other operations' state vector, e.g. purchases of production materials, feeds. 
Control vector $u(t)=u_{i j}(t)$ presents the flows inside the farm or between the farm and its surroundings. This vector's components describe acreages of subsequent crops, livestock class change, livestock sale or purchase, during the farms transition from state $t$ to $t+l$. The $i, j$ indices determine the order of succession, e.g. after a crop $i, \operatorname{crop} j$ will be grown, or an animal of $i$ class will pass into the $j$ class.

Dynamics equations for crop production take the form of:

$$
x_{i}(t+1)=\sum u_{p i}(t)
$$

where:

$x_{i}(t+1)$ - acreage of $i$-th arable crop in the year $t+l$,

$u_{p i}(t)$ - acreage of various forecrops $\mathrm{p}$ after which $i$-th is grown in the year $t+l$.

The dynamics equations' form for livestock production is as follows:

$$
x_{i}(t+1)=x_{i}(t)-u_{i s}(t)+u_{i z}(t)+u_{j i}(t)
$$

where:

$x_{i}(t+1)-i$-th species' livestock state in the year $t+l$.

$x_{i}(t)-i$-th species' livestock state in the preceding year,

$u_{i s}(t)-i$-th species' livestock sales in the $t$ year,

$u_{i z}(t)-i$-th species' livestock purchase in the $t$ year,

$u_{j i}(t)-i$-th species' livestock quantity from own livestock, reclassing.

To sum up, it should be said that dynamics and constraints linear equations transition the farm from state $t$ to state $t+l$, meaning from the previous to the next research year. They incorporate: the farm's state in the year $t$, control that could be utilized while transitioning from state $t$ to state $t+l$, and limits of agricultural production.

The goal criterion vectors $m(t), w(t+1)$ apply to individual agricultural income of variable controls and states leading to commodity activities or individual costs incurred in case of subsistence activities and production materials' prices (feeds, fertilizers) and agricultural products (excessing livestock's nutritional needs). In the stochastic programming model with random goal function, the parameters of these vectors are random variables. Let us assume that ( $\mathrm{t}$ facilitate formulations) these vectors are collectively named $C$, and the variables of control $u(t)$ and state $x(t+1)$ - form a vector $X^{\prime}$.

Control criterion can then be formulated as:

$$
Z=C T X^{\prime} \rightarrow \max
$$


where:

$C$ - vector of random variables with expected values of $E\left(C_{i}\right)=c_{i}$, variations $D^{2}\left(C_{i}\right)=s^{2}$ fir $i=1,2, \ldots, n$ and covariations of $\operatorname{cov}\left(C_{i}, C_{j}\right)=s_{i j}$ for $j=$ $=1,2, \ldots, m$.

Three methods will be used to solve such a model, which one calls model E, $\mathrm{V}$ and VE of stochastic programming. One of the first people to formulate and describe the idea of such programming was Tintner [1955].

Of the expected value of vector $C$ presented $E(C)=c=\left(c_{1}, c_{2}, \ldots, c_{n}\right)$, the goal function (9) could be reduced to the form of:

$$
E(Z)=E\left(c^{T} X^{\prime}\right)=c^{T} X^{\prime} \rightarrow \max
$$

The model determined with formulas (1)-(3) and (10) is a determined task of linear programming. Its solution is the vector of control and state variables $X_{E}^{\prime}$ and the maximum value of $z_{E}$ reachable in given conditions. This model is called E stochastic programming model and its goal function variations are determined by the formula:

$$
X_{E}^{\prime T} S X_{E}^{\prime}=\delta_{E}^{2}
$$

where:

$S$ - goal function parameters' variance and covariance matrix.

This variance measures the risk that might turn out to be too high for the decision maker. In the stochastic programming $\mathrm{V}$ model, $\mathrm{Z}$ random variable's variance is assumed as the goal function that is to be minimized. It takes the form of:

$$
D^{2}(Z)=X^{T} S X^{\prime} \rightarrow \min
$$

This function is quadratic, therefore solution of a model created by the (1)-(3) limits and function (12) is only possible through utilization of quadratic programming algorithm. The $\mathrm{V}$ model's solution is the $X_{V}^{\prime}$ variables of state and control's vectors, and the lowest $\delta_{V E}^{2}$ variance that can be acquired with the given limitations. The $\mathrm{z}_{\mathrm{y}}$ expected value is obtained from the formula:

$$
z_{V}=c^{T} X_{V}^{\prime}
$$


This value bears a slight risk, but it can be too low for the decision maker. If another limitation is introduced to the $\mathrm{V}$ model, one imposed on the expected value of goal function in the form of:

$$
c^{T} X^{\prime} \geq d_{i}
$$

where:

$d_{i}-$ allowed value from the $\left[z_{V}, z_{E}\right]$ interval, i.e. from the interval with endings indicated by the expected value in the $\mathrm{V}$ and $\mathrm{E}$ models, then the model created by the (1)-(3), (14) balance conditions and the (12) goal function will be called the stochastic programming VE model. This model will be solved with quadratic programming and will allow for choosing the $z_{V E}$ expected value, favorable for the decision maker (calculated from the (13) formula), bearing acceptable risk of $\delta_{V E}^{2}$.

\section{Construction of models with random parameters of the objective function}

Two models with random goal function parameters were built for an average Polish farm. The first, consisting of 44 state ad control variables and 64 limiting and dynamics conditions, described a crop-oriented farm. The second one, with 86 variables and 138 conditions, related to a farm dealing with crop and livestock production. Statistical data on farms from the years 2009-2012 [CSO 2014] was used for creation of the models. The data related to the sown area and permanent pasture, sowing structure, yields, fertilization, the amount of livestock, livestock production efficiency and the purchase prices of agricultural products. Moreover, livestock nutritional standards and workload related to individual crops and livestock species were determined based on the literature [Kowalak 1997]. Table 1 presents basic data for an average farm in the analyzed years.

Information included in the table confirms the diversity of production (fluctuations in yields) and economic (price instability) conditions, and indicates the need of including risk in agricultural production. The gathered data represented technical and economical parameters, free expressions of optimization models, and was used for the goal function factors' calculation. Individual income in the crop model was the difference between production value (price $\mathrm{x}$ yield) and production cost [Augustyńska-Grzymek 2012]. The acquired income was increased 
Table 1

Basic characteristics of a the average Polish farm

\begin{tabular}{|c|c|c|c|c|}
\hline Specification & 2009 & 2010 & 2011 & 2012 \\
\hline Sown area [ha] & 7.78 & 7.95 & 8.06 & 8.22 \\
\hline Grasslands area [ha] & 2.21 & 2.36 & 2.45 & 2.64 \\
\hline Pastures area [ha] & 1.87 & 2.05 & 1.98 & 2.69 \\
\hline $\begin{array}{l}\text { Structure of sown [\%] } \\
\text { of which: } \\
\text { cereals } \\
\text { industrial crops } \\
\text { potatoes } \\
\text { feed crops } \\
\text { pulses crops } \\
\text { other crops }\end{array}$ & $\begin{array}{c}100 \\
73.9 \\
9.1 \\
4.4 \\
8.0 \\
1.1 \\
3.5\end{array}$ & $\begin{array}{l}100 \\
73.2 \\
11.6 \\
3.7 \\
7.0 \\
1.7 \\
2.8\end{array}$ & $\begin{array}{c}100 \\
73.8 \\
10.2 \\
3.7 \\
8.3 \\
1.5 \\
2.5 \\
\end{array}$ & $\begin{array}{c}100 \\
73.7 \\
9.1 \\
3.4 \\
10.8 \\
0.4 \\
2.6 \\
\end{array}$ \\
\hline $\begin{array}{c}\text { Yields }\left[\mathrm{dt} \cdot \mathrm{ha}^{-1}\right] \text { : } \\
\text { cereals } \\
\text { rape } \\
\text { potatoes } \\
\text { sugar beets } \\
\text { grasslands } \\
\text { pastures }\end{array}$ & $\begin{array}{c}34.8 \\
30.8 \\
191 \\
543 \\
49.2 \\
204\end{array}$ & $\begin{array}{c}35.6 \\
23.6 \\
211 \\
483 \\
49 \\
192\end{array}$ & $\begin{array}{c}34.3 \\
22.4 \\
232 \\
574 \\
50.5 \\
210\end{array}$ & $\begin{array}{c}34.6 \\
26.4 \\
242 \\
582 \\
51.9 \\
196\end{array}$ \\
\hline $\begin{array}{l}\text { Procurement prices }\left[\mathrm{PLN} \cdot \mathrm{dt}^{-1}\right]: \\
\text { wheat } \\
\text { barley } \\
\text { rye } \\
\text { oats } \\
\text { triticale } \\
\text { potatoes } \\
\text { sugar beets } \\
\text { rape } \\
\text { beef for slaughter }\left[\mathrm{PLN} \cdot \mathrm{kg}^{-1}\right] \\
\text { pork for slaughter }\left[\mathrm{PLN} \cdot \mathrm{kg}^{-1}\right] \\
\text { milk }\left[\mathrm{PLN} \cdot \mathrm{I}^{-1}\right]\end{array}$ & $\begin{array}{c}48.26 \\
32.74 \\
40.8 \\
30.82 \\
37.05 \\
31.73 \\
11.57 \\
108.24 \\
4.52 \\
4.56 \\
0.9\end{array}$ & $\begin{array}{c}59.84 \\
41.12 \\
48.98 \\
34.30 \\
46.65 \\
36.53 \\
11.31 \\
127.76 \\
4.56 \\
3.89 \\
1.07\end{array}$ & $\begin{array}{c}81.99 \\
74.24 \\
75.38 \\
64.34 \\
72.01 \\
37.0 \\
14.40 \\
183.91 \\
5.58 \\
4.52 \\
1.21\end{array}$ & $\begin{array}{c}88.68 \\
74.40 \\
81.49 \\
65.07 \\
79.56 \\
37.76 \\
13.72 \\
183.91 \\
6.40 \\
5.45 \\
1.20\end{array}$ \\
\hline $\begin{array}{l}\text { Number of cows } \\
\text { Number of sows }\end{array}$ & $\begin{array}{l}4 \\
3 \\
\end{array}$ & $\begin{array}{l}3 \\
2 \\
\end{array}$ & $\begin{array}{l}3 \\
2 \\
\end{array}$ & $\begin{array}{l}2 \\
1\end{array}$ \\
\hline $\begin{array}{l}\text { Fertilizer use of NPK in kg } \\
\text { per ha of agricultural land }\end{array}$ & 117,9 & 114,6 & 126,6 & 125,1 \\
\hline Employment & 1,97 & 1,95 & 1,95 & 1,94 \\
\hline
\end{tabular}

Source: Own work based on statistical data Central Statistical Office (CSO).

by subsidies. In the livestock breeding model, the calculation method of individual income for commodity production variables was not changed. However, the crops intended for livestock feed and the livestock for breeding as a goal function were burdened with cost reduced by subsidies, and the mineral fertilizers and concentrated mixtures with the individual purchase price. Prices of variables related to livestock only included veterinarian services, livestock insurance and used electric energy. Livestock feeding was accomplished with own feeds (va- 
lued according to production costs) except purchased mixtures (market prices). Excess harvested forage exceeding the nutritional needs were allocated for sale. Moreover, agricultural income for the years 2004-2012 was calculated (period with EU grants) and on its basis the variance and covariance matrix was indicated as the risk measure. In order to reflect processes occurring in a farm as accurately as possible, the models encompass a series of balances ensuring proper succession of crops and their fertilization, proper livestock feeding, optimization of farm-produced feeds' utilization and the necessary amount of purchased feeds, proper need for workforce). Dynamics equations called the model's binding equations were related to rotation of crops and livestock herd. They connected the model's individual stages (years of research) into a linear-dynamic optimization model. The total area of crops and permanent pastures, the amount of cows and sows, and the number of working hours (equations' free expressions) were assumed as the average value for the studied years.

\section{Solutions for models with random goal function parameters}

Three algorithms called the V, E and VE model were used for solving the linear-dynamics models with random goal function parameters. The limitation introduced into the VE model, assuming that expected value of agricultural income may be lower than in the E model, but at least as high as in the $\mathrm{V}$ model, gives an infinite number of solutions. This range was divided into 5 sections for analyses. All the calculations were done with the MATLAB suite with added subprograms allowing for solving stochastic optimization models of linear and quadratic programming.

The result of each crop production model's solution was the acreage, value of agricultural income and the risk related to its acquisition. Table 2 presents the agricultural income and risk acquired in the four analyzed years' optimal solutions.

The income in the $\mathrm{V}$ and $\mathrm{VE}_{1}$ models, as well as in the $\mathrm{E}$ and $\mathrm{VE}_{6}$ models, is identical due to the models' foundations. Standard deviation in the VE models increases proportionally to the agricultural income's increase. The difference of risk value in the $\mathrm{VE}_{6}$ model compared to the $\mathrm{E}$ model is due to utilization of different research methods. The lowest income was acquired in the $\mathrm{V}$ model at a relatively low risk $(9.44 \%)$. The highest income, however, was achieved in solutions making use of the $\mathrm{E}$ and $\mathrm{VE}_{6}$ algorithm, but the risk of its realization was respectively: $14.07 \%$ and $10.04 \%$. The $\mathrm{VE}_{5}$ solution seems, therefore, more favorable where income decreased by $0.65 \%$ compared to the $\mathrm{VE}_{6}$ model causing a decrease in risk by $2.33 \%$. Table 3 presents the production structure acquired in the solutions of $\mathrm{V}, \mathrm{E}$ and $\mathrm{VE}_{5}$ models. 
Table 2

The values of agricultural income and its risk in a crop production model

\begin{tabular}{|c|c|c|c|}
\hline Model type & $\begin{array}{c}\text { Farm income } \\
{[\mathrm{PLN}]}\end{array}$ & $\begin{array}{c}\text { Variance } \\
{[\mathrm{PLN}]}\end{array}$ & $\begin{array}{c}\text { Standard deviation } \\
{[\mathrm{PLN}]}\end{array}$ \\
\hline $\mathrm{E}$ & 70516.55 & 98406096.61 & 9919.98 \\
\hline $\mathrm{V}=\mathrm{VE}_{1}$ & 68205.76 & 41490345.69 & 6441.30 \\
\hline $\mathrm{VE}_{2}$ & 68667.92 & 42631758.49 & 6529.30 \\
\hline $\mathrm{VE}_{3}$ & 69130.08 & 43896455.19 & 6625.44 \\
\hline $\mathrm{VE}_{4}$ & 69592.24 & 45627728.33 & 6754.83 \\
\hline $\mathrm{VE}_{5}$ & 70054.39 & 47799939.06 & 6913.75 \\
\hline $\mathrm{VE}_{6}$ & 70516.55 & 50109409.44 & 7078.80 \\
\hline
\end{tabular}

Source: Author's own calculations on Matlab program.

Table 3

Acreage in the consecutive years

\begin{tabular}{|c|c|c|c|c|}
\hline \multirow{2}{*}{ Variables [ha] } & \multicolumn{4}{|c|}{ Years } \\
\hline & 2009 & 2010 & 2011 & 2012 \\
\hline \multicolumn{5}{|c|}{ Model V } \\
\hline Wheat & 0 & 0 & 0.8 & 0.88 \\
\hline Barley & 0.96 & 5.36 & 0 & 0 \\
\hline Rye & 0.4 & 0.48 & 0.64 & 5.04 \\
\hline Oats & 4.56 & 0 & 0 & 0 \\
\hline \begin{tabular}{|l|} 
Triticale \\
\end{tabular} & 0 & 0 & 4.48 & 0 \\
\hline \begin{tabular}{|l|} 
Rape \\
\end{tabular} & 0.88 & 0.96 & 0.88 & 0.80 \\
\hline Potatoes & 0.2 & 0.18 & 0.42 & 0.96 \\
\hline Sugar beets & 0.6 & 0.62 & 0.46 & 0 \\
\hline Other crops & 0.4 & 0.4 & 0.32 & 0.32 \\
\hline Stubble catch crop & 0.4 & 0.48 & 0.64 & 0.8 \\
\hline \multicolumn{5}{|c|}{ Model E } \\
\hline Wheat & 0.96 & 1.24 & 0.8 & 0.88 \\
\hline Barley & 0 & 4.12 & 0 & 0 \\
\hline Rye & 0.4 & 0.48 & 0.64 & 5.04 \\
\hline Oats & 4.56 & 0 & 0 & 0 \\
\hline Triticale & 0 & 0 & 4.48 & 0 \\
\hline Rape & 0.88 & 0.96 & 0.88 & 0.8 \\
\hline Potatoes & 0.2 & 0.18 & 0.23 & 0.36 \\
\hline Sugar beets & 0.6 & 0.62 & 0.65 & 0.6 \\
\hline Other crops & 0.4 & 0.4 & 0.32 & 0.32 \\
\hline Stubble catch crop & 0.4 & 0.48 & 0.64 & 0.8 \\
\hline \multicolumn{5}{|c|}{ Model VE 5} \\
\hline Wheat & 0.96 & 1.24 & 0.8 & 0.88 \\
\hline Barley & 0 & 4.12 & 0 & 0 \\
\hline Rye & 0.4 & 0.48 & 0.64 & 5.04 \\
\hline Oats & 4.56 & 0 & 0 & 0 \\
\hline Triticale & 0 & 0 & 4.48 & 0 \\
\hline Rape & 0.88 & 0.96 & 0.88 & 0.8 \\
\hline Potatoes & 0.2 & 0.18 & 0.23 & 0.25 \\
\hline Sugar beets & 0.6 & 0.62 & 0.65 & 0.71 \\
\hline Other crops & 0.4 & 0.4 & 0.32 & 0.32 \\
\hline Stubble catch crop & 0.4 & 0.48 & 0.64 & 0.8 \\
\hline
\end{tabular}

Source: Author's own calculations on Matlab program. 
Stubble aftercrop (sown after rye harvest) and plowed straw of cereals and oilseed rape were the source of soil organic matter in those models. Moreover, solutions in the model indicated an excess in workforce in an average crop production-only farm.

As a result of the livestock production-only model, with three algorithms, information was acquired regarding the acreage, amount of livestock of individual species and classes, the amount of sold crop products (excessing the nutritional needs of livestock) and purchased concentrated feeds, the demand for workforce, acquired agricultural income and the risk related to its realization. Table 4 presents the values of agricultural income and its risk.

\section{Table 4}

The values of agricultural income and its risk in a livestock production model

\begin{tabular}{|c|c|c|c|}
\hline Model type & $\begin{array}{c}\text { Farm income } \\
{[\mathrm{PLN}]}\end{array}$ & $\begin{array}{c}\text { Variance } \\
{[\mathrm{PLN}]}\end{array}$ & $\begin{array}{c}\text { Standard deviation } \\
{[\mathrm{PLN}]}\end{array}$ \\
\hline $\mathrm{E}$ & 121678.60 & 156266982.40 & 12500.68 \\
\hline $\mathrm{V}=\mathrm{VE}_{1}$ & 87873.63 & 25036713.47 & 5003.67 \\
\hline $\mathrm{VE}_{2}$ & 94634.62 & 29397975.56 & 5421.99 \\
\hline $\mathrm{VE}_{3}$ & 101395.61 & 42378537.61 & 6509.88 \\
\hline $\mathrm{VE}_{4}$ & 108156.60 & 48747905.08 & 6981.97 \\
\hline $\mathrm{VE}_{5}$ & 114917.59 & 56077033.17 & 7488.46 \\
\hline $\mathrm{VE}_{6}$ & 121678.58 & 78133578.06 & 8839.32 \\
\hline
\end{tabular}

Source: Author's own calculations on Matlab program.

The agricultural income acquired in the years 2009-2012 in all the crop and livestock production model's solutions was higher than the crop production-only model's solutions (the increase fluctuated from $28.84 \%$ in the $\mathrm{V}$ and $\mathrm{VE}_{1}$ model to $72.55 \%$ in the $\mathrm{E}$ and $\mathrm{VE}_{6}$ model). Moreover, this model's realization was less risky than in crop production-only farms. The standard deviation varied from $5.69 \%$ of income in the $\mathrm{V}$ and $\mathrm{VE}_{1}$ solution to $10.27 \%$ in the $\mathrm{E}$ model. The lesser uncertainty in livestock production was probably resulting from the limited influence of agro-climatic conditions on livestock breeding. The model predicted a purchase of feeds in case of absence thereof. Table 5 presents the production structure resulting from the livestock model's solutions with the $\mathrm{V}, \mathrm{E}$ and $\mathrm{VE}_{5}$ algorithm.

The crop structure in the $\mathrm{V}$ and $\mathrm{VE}_{5}$ solutions is identical. The changes relate to livestock breeding and the amount of sold crop products (those variables were not indicated in table 5). The livestock fractional numbers indicate of a specimen not having been at the farm a full year. The labor-intensive livestock production increased the farm's income and provided organic fertilizers necessary for cultivation of especially root crops. Milk production and sales of young cattle and pigs for fattening were the main causes for income growth. The existing workforce was fully utilized in an average livestock farm in the period of peak demand for it (harvest, excavation). 
Table 5

Basic variables in livestock and crop model

\begin{tabular}{|c|c|c|c|c|}
\hline \multirow{2}{*}{ Variables } & \multicolumn{4}{|c|}{ Years } \\
\hline & 2009 & 2010 & 2011 & 2012 \\
\hline \multicolumn{5}{|c|}{ Model V } \\
\hline Wheat [ha] & 0 & 0 & 0 & 0 \\
\hline Barley [ha] & 5.44 & 0.88 & 0.8 & 0.88 \\
\hline Rye [ha] & 0.40 & 0.48 & 5.12 & 0.56 \\
\hline Oats [ha] & 0.08 & 0 & 0 & 4.48 \\
\hline Triticale [ha] & 0 & 4.48 & 0 & 0 \\
\hline Rape [ha] & 0.88 & 0.96 & 0.88 & 0.80 \\
\hline Potatoes [ha] & 0.32 & 0.32 & 0.32 & 0.48 \\
\hline Sugar beets [ha] & 0.48 & 0.48 & 0.56 & 0.48 \\
\hline Other crops [ha] & 0.40 & 0.40 & 0.32 & 0.32 \\
\hline Cows [heads] & 3 & 3 & 3 & 3 \\
\hline Calves [heads] & 0 & 1.95 & 0 & 0 \\
\hline Beef cattle [heads] & 2 & 0 & 1.56 & 0 \\
\hline Sows [heads] & 2 & 2 & 2 & 2 \\
\hline Piglets [heads] & 32 & 8.19 & 8.19 & 32 \\
\hline Porkers [heads] & 32 & 0 & 7.94 & 7.94 \\
\hline \multicolumn{5}{|c|}{ Model E } \\
\hline Wheat [ha] & 0 & 0 & 0.8 & 0 \\
\hline Barley [ha] & 0.96 & 0.88 & 0 & 5.36 \\
\hline Rye [ha] & 0.40 & 4.96 & 0.64 & 0.56 \\
\hline Oats [ha] & 0.08 & 0 & 4.48 & 0 \\
\hline Triticale [ha] & 4.48 & 0 & 0 & 0 \\
\hline Rape [ha] & 0.88 & 0.96 & 0.88 & 0.80 \\
\hline Potatoes [ha] & 0.32 & 0.32 & 0.32 & 0.48 \\
\hline Sugar beets [ha] & 0.48 & 0.48 & 0.56 & 0.48 \\
\hline Other crops [ha] & 0.40 & 0.40 & 0.32 & 0.32 \\
\hline Cows [heads] & 3 & 3 & 3 & 3 \\
\hline Calves [heads] & 2.94 & 2.94 & 2.94 & 2.94 \\
\hline Beef cattle [heads] & 2 & 2.35 & 2.35 & 2.35 \\
\hline Sows [heads] & 2 & 2 & 2 & 2 \\
\hline Piglets [heads] & 32 & 32 & 32 & 32 \\
\hline Porkers [heads] & 32 & 31.04 & 31.04 & 31.04 \\
\hline \multicolumn{5}{|c|}{ Model VE ${ }_{5}$} \\
\hline Wheat [ha] & 0 & 0 & 0 & 0 \\
\hline Barley [ha] & 5.44 & 0.88 & 0.8 & 0.88 \\
\hline Rye [ha] & 0.40 & 0.48 & 5.12 & 0.56 \\
\hline Oats [ha] & 0.08 & 0 & 0 & 4.48 \\
\hline Triticale [ha] & 0 & 4.48 & 0 & 0 \\
\hline Rape [ha] & 0.88 & 0.96 & 0.88 & 0.80 \\
\hline Potatoes [ha] & 0.32 & 0.32 & 0.32 & 0.48 \\
\hline Sugar beets [ha] & 0.48 & 0.48 & 0.56 & 0.48 \\
\hline Other crops [ha] & 0.40 & 0.40 & 0.32 & 0.32 \\
\hline Cows [heads] & 3 & 3 & 3 & 3 \\
\hline Calves [heads] & 2.94 & 2.94 & 2.94 & 2.94 \\
\hline Beef cattle [heads] & 2 & 2.35 & 2.35 & 2.35 \\
\hline Sows [heads] & 0 & 0 & 0 & 0 \\
\hline Piglets [heads] & 0 & 0 & 0 & 0 \\
\hline Porkers [heads] & 32 & 0 & 0 & 0 \\
\hline
\end{tabular}

Source: Author's own calculations on Matlab program. 


\section{Conclusions}

Two linear-dynamic optimization models were constructed for an average Polish farm based on statistical data. One of them concerned a livestock production-only farm, and the other a livestock and crop production farm. Random variables were present in these models as goal functions, so stochastic programming was used for solving them, specifically its three algorithms (E, V and VE models) taking the decision maker's preferences into account. Acquisition of highest agricultural income was made possible by the E model but achieving it was too risky. As the cost of goal criterion expected value decrease (compared to the E model), the $\mathrm{V}$ model allowed for reaching a solution with smaller variance, and thus more certain realization. Such a solution was not favorable for the decision maker because of agricultural income being too low. The VE model, on the other hand, allowed for choosing the right solution variant.

The agricultural income reached in the crop and livestock production model's solutions was significantly higher than in the crop model's solutions. The differences varied from 28.84 to $72.55 \%$. Moreover, the risk of income realization in livestock models was lower. Risk did not exceed $15 \%$ in any of the solutions. The $\mathrm{VE}_{5}$ model yielded a favorable solution in terms of expected value and standard deviation. It allowed for significantly lowering the risk (compared with the E model) in both livestock and non-livestock farm, with a slight agricultural income reduction.

The most lucrative production lines include cultivation of oilseed rape, sugar beet and cow breeding. Industrial crop acreage in the solutions was always the upper limit in the assigned crop structure participation. Cows were included in every solution due to milk production.

Linear-dynamic models with random goal function allowed for assessing the risk related to reaching the determined agricultural income. It can therefore be used as a support tool for income study of farms under conditions of uncertainty.

\section{References}

AUGUSTYŃSKA-GRZYMEK I. (red.), 2012: Produkcja, koszty $i$ dochody z wybranych produktów rolniczych, Wydawnictwo Instytutu Ekonomiki Rolnictwa i Gospodarki Żywnościowej - Państwowego Instytutu Badawczego.

CSO (GUS): http://www.stat.gov.pl/bdl/app/dane_cechter.display?p_id=532775\&p_token= 0.593056982760536 (accessed on: 02/03/2014).

JAJUGA K., 2007: Zarzadzanie ryzykiem, Wydawnictwo Naukowe PWN, Warszawa.

KRAWIEC B., 1991: Metody optymalizacji w rolnictwie, PWN, Łódź.

KOWALAK Z., 1997: Ekonomika i organizacja rolnictwa, część 1, eMPi2. 
KUZIAK K., 2011: Pomiar ryzyka przedsiębiorstwa. Modele pomiaru i ich ryzyko, Wydawnictwo Uniwersytetu Ekonomicznego we Wrocławiu, Wrocław.

MILLER A., DOBBINS C., PRITCHETT J., BOEHLJE M., EHMKE C., 2004: Risk Management for Farmers. Department of Agricultural Economics, Purdue University.

TINTNER G., 1955: Stochastic linear programming with applications to agricultural economics. National Bureau of Standards, Washington.

\section{Ryzyko związane z produkcją rolniczą w przeciętnym gospodarstwie rolnym w Polsce}

\section{Streszczenie}

Dla przeciętnego gospodarstwa rolnego w Polsce zbudowano liniowo-dynamiczne modele optymalizacyjne z losowymi parametrami funkcji celu. Do rozwiązywania tych modeli wykorzystano trzy algorytmy: maksymalizujący dochód rolniczy, minimalizujący ryzyko jego osiagnięcia i minimalizujący ryzyko uzyskania dochodu z określonego przedziału. Algorytmy te wykorzystują w trakcie obliczeń programowanie liniowe i kwadratowe. Wyniki rozwiązań wskazują plany produkcji, których realizacja umożliwia osiagnnięcie najwyższego $\mathrm{w}$ danych warunkach dochodu rolniczego bądź najniższego ryzyka związanego z realizacją dochodu. Miarą ryzyka jest odchylenie standardowe wyznaczone na podstawie macierzy wariancji i kowariancji dochodów rolniczych uzyskanych w latach 2006-2012. Cel tej pracy to ukazanie ryzyka związanego z produkcją rolnicza, której efektem jest uzyskany dochód rolniczy. 